\title{
Formation of the Entrepreneurial Potential of Student Youth: A Factor of Work Experience
}

\author{
Nataliya Chukhray ${ }^{1}$, Michal Greguš ${ }^{2}\left(\mathbb{D}\right.$, Oleh Karyy $^{1, * \mathbb{C}}$ and Liubov Halkiv ${ }^{1}(\mathbb{D}$ \\ 1 Institute of Economics and Management, Lviv Polytechnic National University, 12 Stepan Bandera St, \\ 79013 Lviv, Ukraine; natalia.i.chuhraj@lpnu.ua (N.C.); lubov.i.halkiv@lpnu.ua (L.H.) \\ 2 Faculty of Management, Comenius University in Bratislava, 10 Odbojárov, 83104 Nové Mesto, Slovak; \\ michal.gregusml@fm.uniba.sk \\ * Correspondence: oleh.i.karyi@lpnu.ua
}

Citation: Chukhray, N.; Greguš, M.; Karyy, O.; Halkiv, L. Formation of the Entrepreneurial Potential of Student Youth: A Factor of Work Experience. Mathematics 2021, 9, 1494. https:// doi.org/10.3390/math9131494

Academic Editors: David Carfi and Vladimir A. Plotnikov

Received: 5 May 2021

Accepted: 17 June 2021

Published: 25 June 2021

Publisher's Note: MDPI stays neutral with regard to jurisdictional claims in published maps and institutional affiliations.

Copyright: (c) 2021 by the authors. Licensee MDPI, Basel, Switzerland. This article is an open access article distributed under the terms and conditions of the Creative Commons Attribution (CC BY) license (https:// creativecommons.org/licenses/by/ $4.0 /)$.

\begin{abstract}
International norms regarding educational activity are aimed at forming entrepreneurial competencies in students. The motivational readiness of student youth to implement these entrepreneurial competencies in practice reflects the potential for entrepreneurship development. Despite the social group of student youths being considered belonging to the category of economically inactive population, students are traditionally engaged in social production. New changes in labor and consumption conditions of higher education services contribute to the growing trend in students who combine study and work. Considering this trend, we investigate the impact of students' work experience on forming their entrepreneurial potential. The analytical component of this study is performed according to the materials obtained through a questionnaire, which covers 746 students. The findings prove that students who engage in employment before studying at university tended to combine university studies and employment in social production. Having such an employment experience increases students' confidence regarding their entrepreneurial abilities and has a positive effect on students' intentions to start their own businesses. Simultaneously, the lack of experience in management assistance does not constrain students' intentions to start a business.
\end{abstract}

Keywords: student youth; work experience; entrepreneurial potential; secondary employment

\section{Introduction}

International norms of educational activity are aimed at achieving a number of learning outcomes, including meeting the demand to form the ability of students to conduct the entrepreneurial activity. In Ukraine, this requirement is described by the law On Education [1] as competence in "entrepreneurship and financial literacy". At the EU level, as an example, the Framework Program of the updated key competencies for lifelong learning was introduced [2], providing entrepreneurship competence in students (entrepreneurship competence). Motivational readiness to perform the entrepreneurial competencies in practice reflects the potential of entrepreneurship development, and thus, the potential of socio-economic development of society.

In the 21st century, governments of developed countries, the public, and the business community have identified higher education as a key driver of social development. The progressive role of higher education and its traditional providers, universities, in the generation of the intellectual and innovative assets of society was proved by various scientific studies, verified in the concepts related to the knowledge-based economy. However, the dynamics of social transformations require new research. In particular, it is important to study the role of higher education in shaping the entrepreneurial potential of society in modern realities.

In recent years, student youth employment has shown a tendency to increase. This trend poses a number of threats. Among these are the change in student priorities during the student period of life in favor of personal income, material wealth, and financial 
independence, which may lead to a decrease in opportunities, and often, in the desire to pay more attention to learning [3]. Simultaneously, this trend has a number of obvious advantages associated with accelerating the processes of students' social adaptation to the labor market and their financial independence. The positive effects of student employment should also be considered from a strategic dimension. The practical experience gained by students can form the basis of their own entrepreneurial potential and contribute to its transformation into entrepreneurial capital.

Discussion is ongoing in the scientific literature on whether a relationship exists between work experience and entrepreneurial intentions of bachelor students. For example, Idarti et al. [4], who studied students in Indonesia, Japan, South Korea, Taiwan, and Thailand, did not find evidence of such a relationship. Conversely, Miranda et al. [5], who studied the determinants of entrepreneurial intention in Spanish universities, found that professional experience had a positive influence on entrepreneurial intentions through partial least squares regression data analysis. Fatoki [6] studied the influences of entrepreneurship education and previous work experience on the entrepreneurial intention of undergraduate students in South Africa, and using descriptive statistics, found that students with previous work experience had a higher level of entrepreneurial intention compared with students without previous work experience, but the $t$-test showed that the difference was not statistically significant.

Based on the latest conditions of employment, digitalization of higher education services, flexible approaches in the educational process, and changes in the values of modern youth, student employment will continue to grow. Given this trend, we aimed to explore the impact of students' work experience on forming their entrepreneurial potential.

The remainder of this article is structured as follows: Based on a review of the scientific literature, the different views on the role of work experience in forming entrepreneurial competencies of student youth are substantiated, and a niche is outlined for research, which involves testing four hypothetical assumptions about the impact of previous work experience on the desire to start their own business by first-year undergraduate students. Based on a survey of students, the statistical distributions of their answers were analyzed to examine the hypothetical assumptions. Per the results of the analysis, we then provide generalized conclusions.

\section{Literature Review}

Many works in different countries around the world have addressed the factors influencing students' intentions. Bell [7] studied the impact of the initiative, attitude toward risk, innovativeness, and self-efficacy on the entrepreneurial intentions of students in the U.K. Herman [8] studied the entrepreneurial intentions of Romanian students in technical specialties and their main determinants. A similar study was conducted by Asimakopoulos et al. [9] on the influence of social norms on the interaction between business education and the intention to conduct business activities, as well as social norms on the interaction between entrepreneurial self-performing and entrepreneurial intentions of technical specialties students in Spain. In turn, the factors influencing entrepreneurial intentions of economic specialties students in Malaysia were studied by Saleh and Idris [10]. The role of team cooperation during entrepreneurship education in the entrepreneurial self-efficacy and entrepreneurial passion of bachelor students in China was studied by $\mathrm{Li}$ and $\mathrm{Wu}$ [11]. Entrepreneurship education, curriculum, and teacher competence as factors in shaping students' entrepreneurial intentions were studied by Iwu et al. [12] and Prokopenko et al. [13]. Şahin et al. [14] determined the personal characteristics of people that contribute to new intentions to start a business. Arranz et al. [15] studied entrepreneurial students' intentions and the obstacles experienced by students in starting their own business in Spain. Usman [16], according to the theory of planned behavior (TPB), considered entrepreneurial intentions among foreign students in Turkey.

In the latest scientific research, the issues of entrepreneurial competencies formation in a higher education environment in Ukraine have been considered from various as- 
pects. The essence of entrepreneurial competence was revealed by the following scientists: Pryshchepa [17], Moldavan [18], and Sheligan [19]. Myhovych [20] evidenced the probability of the relationship between mobility as a form of national higher education system internationalization and the process of entrepreneurial competence formation in students of modern universities. Seredina [21] proved that in the structure of entrepreneurial competence of future bachelor's degree in business economics, an important role is played by motivational value and cognitive components. Havran and Havran [22] noted that the process of scientific development commercialization at higher educational institutions, including by creating startups by university students, is a common practice. However, in Ukraine, the issue of the influence of students' practical experience gained through a combination of education and employment on forming their entrepreneurial potential remains rarely studied.

If we analyze the scientific achievements in the field of youth employment, these topics have only been considered from the views of scientists and social institutions. According to the international classification, student youth belonging to the category of economically inactive population. Therefore, employment surveys usually do not address issues related to student employment. This explains the lack of representative data in the State Statistics Service of Ukraine concerning students' employment.

To characterize the labor activity of student youth, the term secondary employment is used, emphasizing the additional form of labor use, which is already considered in social activities. Hrynkevych [3] reported that a peculiar feature of student youth secondary employment is that the primary form of employment is education. Having studied the results of a survey on the values of students' educational and professional orientations, Hrynkevych identified the top three motives for secondary employment: (1) Material income, (2) the opportunity to start a professional career faster, and (3) independence from parents. However, no studies have been conducted in Ukraine on the impact of the secondary employment of students on their entrepreneurial competencies and the potential for their implementation.

\section{Materials and Methods}

The scheme of the research method was as follows: (1) Distribution of anonymous questionnaires during breaks between classes, and collection in paper form among firstyear students of various specialties of Lviv Polytechnic National University; (2) separation of the part of the answers that relate to the employment of students of Lviv Polytechnic and their desire to start their own business from the large-scale questionnaire; (3) selection of valid data from these answers; (4) construction of distributions that provide reasoning about the structure of the answers and the presence (absence) of relationships between them; (5) interpretation of the obtained analysis results.

The analytical component of this study was performed based on the materials of the questionnaire, which was administered in the spring of 2019. The general questionnaire contained 50 questions that focused on a wide range of factors that may affect the entrepreneurial intentions of students. This article is limited to studying the factor of work experience. To achieve our goals, we analyzed the answers to five questions: (1) "Did you work before the beginning of your studies?", (2) "Are you currently working, apart from studying?", (3) "Do you feel that you are an entrepreneurial person?", (4) "Are you going to start your own business?", and (5) "Do you have experience in helping to manage a company?". The survey covered 746 students in their first year of higher education at Lviv Polytechnic National University. This survey was scientific in nature and did not aim to substantiate the representativeness of the sample. Not all answers were valid. The visualization of the answers of respondents in the form of a line chart with accumulation is presented in Figure 1. 


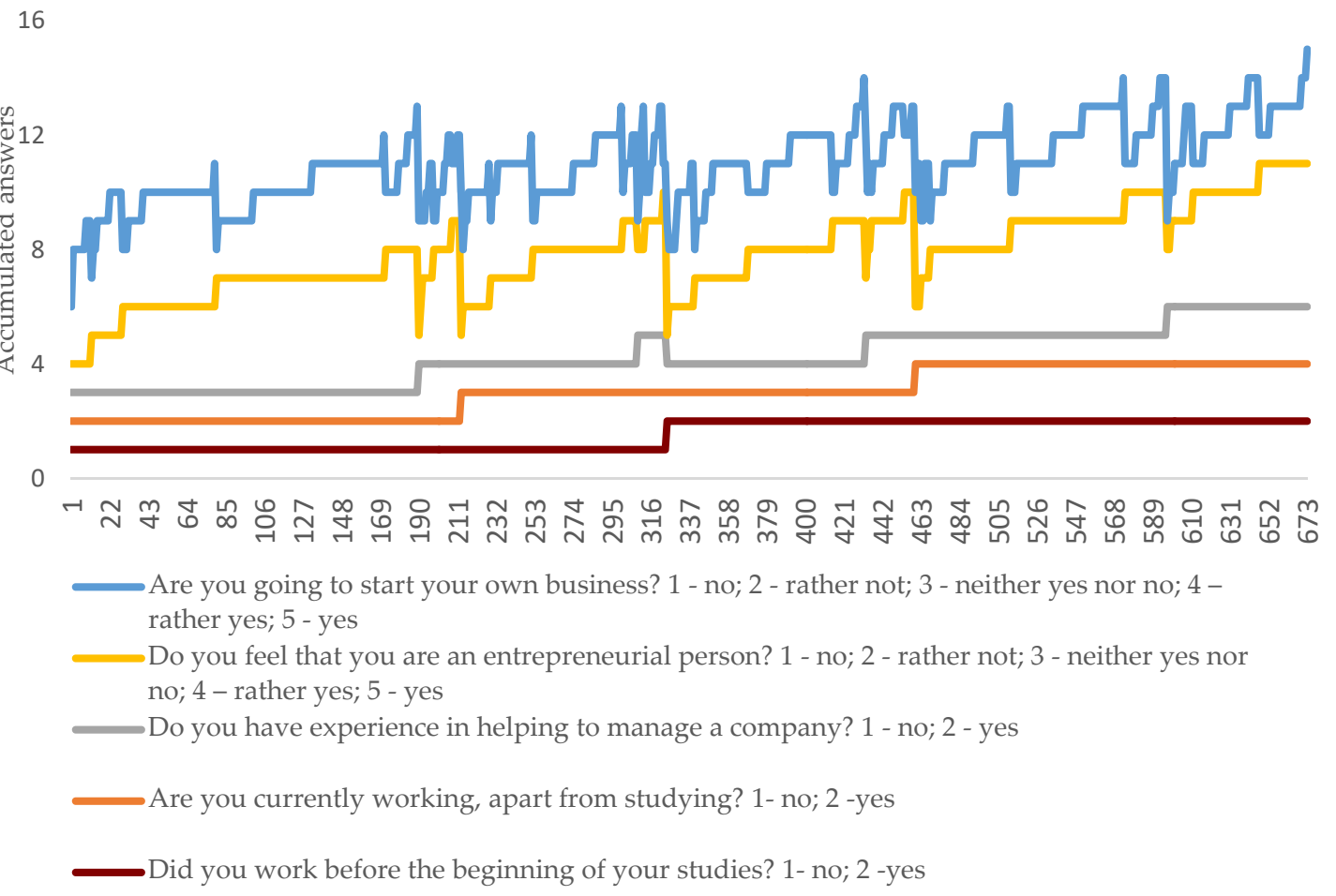

Figure 1. The accumulated answers of the respondents in terms of several questions of the questionnaire.

In addition to the survey method, during the study, we used general scientific methods to summarize and systematize the results. We also used special scientific methods: Statistical analysis, to justify the impact of work experience (employment practice) of students on forming their entrepreneurial potential; and graphical methods, for a visual representation of students' answer distribution in terms of individual questions. The formation of entrepreneurial potential of students is understood as the process of identifying and creating a range of competencies that can now or in the future be used by students in their entrepreneurial activities.

As the answers to different questions were provided in the form of different scales (dichotomous, Likert scale, and nominal scale), we analyzed conjugation tables to assess the relationships using data consolidation.

For analytical purposes, we used indicators of the analysis of conjugation tables:

1. $\chi^{2}$, Pearson's quadratic conjugation (chi-squared):

$$
\chi^{2}=n\left[\sum_{i} \sum_{j} \frac{f_{i j}^{2}}{f_{i \Sigma} \cdot f_{\Sigma j}}-1\right],
$$

where $f_{i j}$ is the frequency of the trait in the $i$ th factor and $j$ th resultant groups; $f_{i \Sigma}$ and $f_{\Sigma j}$ are the final frequencies by groups of factors and result characteristics, respectively; and $n$ is the volume.

2. Cramér's V (C):

$$
C=\sqrt{\frac{\chi^{2}}{n \times\left(m_{\min }-1\right)^{\prime}}}
$$

where $m_{\min }$ is the minimum number of groups by factor $m_{x}$ or the resultant $\left(m_{y}\right)$ attribute.

Certain answers of the respondents were reduced to two options. In this case, we used the following indicators of the analysis of the four-chamber (tetrachoric) table: 
1. Contingency coefficient $(K)$ :

$$
K=\frac{f_{11} \times f_{22}-f_{12} \times f_{21}}{\sqrt{f_{1 \Sigma} \times} f_{2 \Sigma} \times f_{\Sigma 1} \times f_{\Sigma 2}} .
$$

2. Coefficient of association (A):

$$
A=\frac{f_{11} \times f_{22}-f_{12} \times f_{21}}{f_{11} \times f_{22}+f_{12} \times f_{21}} .
$$

3. Odds ratio $(\mathrm{OR})$ :

$$
\text { OR }=\frac{f_{11} \times f_{22}}{f_{12} \times f_{21}}
$$

4. Relative risk (RR):

$$
R R=\frac{f_{11} \times\left(f_{21}+f_{22}\right)}{f_{12} \times\left(f_{11}+f_{12}\right)} .
$$

The lower limit $\left(O R_{L}\right)$ and upper limit $\left(O R_{U}\right)$ of the odds ratio are determined by the following formulas:

$$
\begin{aligned}
& O R_{L}=\exp \left(\ln (O R)-c_{\alpha / 2} \times \sqrt{\frac{1}{f_{11}}+\frac{1}{f_{12}}+\frac{1}{f_{21}}+\frac{1}{f_{22}}}\right) ; \\
& O R_{U}=\exp \left(\ln (O R)+c_{\alpha / 2} \times \sqrt{\frac{1}{f_{11}}+\frac{1}{f_{12}}+\frac{1}{f_{21}}+\frac{1}{f_{22}}}\right),
\end{aligned}
$$

where $c_{\alpha / 2}$ is inverse to the standard normal distribution with a probability of $1-\alpha / 2$ and $\alpha$ is the level of significance.

The lower limit $\left(O R_{L}\right)$ and upper limit $\left(O R_{U}\right)$ of the relative risk are determined by the following formulas:

$$
\begin{aligned}
& R R_{L}=\exp \left(\ln (O R)-c_{\alpha / 2} \times \sqrt{\left.\frac{f_{22}}{f_{21}\left(f_{21}+f_{22}\right)}+\frac{f_{12}}{f_{11}\left(f_{11}+f_{12}\right)}\right)} ;\right. \\
& R R_{U}=\exp \left(\ln (O R)+c_{\alpha / 2} \times \sqrt{\left.\frac{f_{22}}{f_{21}\left(f_{21}+f_{22}\right)}+\frac{f_{12}}{f_{11}\left(f_{11}+f_{12}\right)}\right)} .\right.
\end{aligned}
$$

We used MS Excel to process the survey results and to calculate indicators according to Formulas (1)-(10).

We constructed four hypothetical assumptions:

1. Students who have work experience (practiced employment) before studying at university tend to combine study at university and work.

2. Practical experience leads to higher confidence in students regarding their entrepreneurial abilities.

3. Practical experience has a positive effect on students' intentions to start their own business.

4. Having experience in helping to manage a company has a positive effect on students' intentions to start their own business.

\section{Results}

Valid data on the answers to the questionnaire, "Did you work before study?" and "Are you currently working in addition to studying?", served as the basis of combinational grouping. The first question in the questionnaire was provided with two answer options, and the second, with four (Figure 2). 


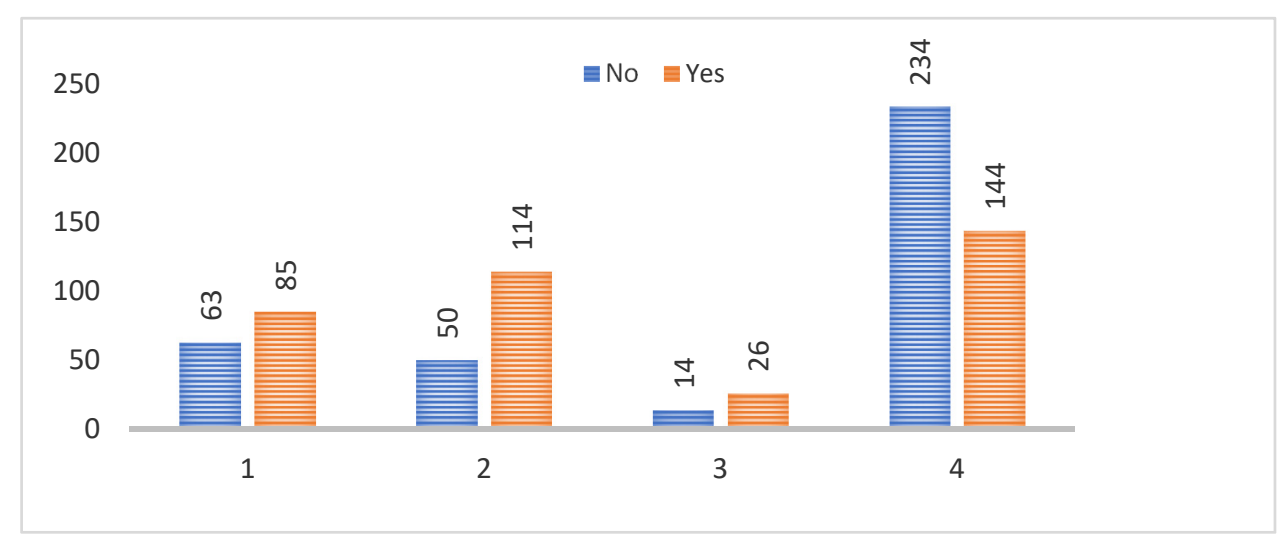

Figure 2. Distribution of respondents by answers to the question, "Did you work before study?" (no, yes) and "Are you currently working in addition to studying?" (1, yes, I have a permanent job; 2, yes, I work part-time/I have an internship; 3, yes, I have my own business; 4, no, I do not work). Source: Compiled by the authors based on their research.

The amount of student employment is evidenced by the data; at the first (bachelor) level of education at the time of the survey, about half of students worked $(22.5 \%$ part-time or interns, $20.3 \%$ had a permanent job, and 5.5\% had their own business). Only 51.8\% of respondents were not working at the time of the survey. A total of $38.1 \%$ had work experience before entering university.

Calculated according to the distribution, shown in Figure 2, the value of the Pearson's quadratic conjugation $\left(\chi^{2}=53.2\right)$ significantly exceeds the theoretical level $\left(\chi^{2}{ }_{0.95}((2-\right.$ $1) \times(4-1))=7.8)$, and the value of Cramér's $\mathrm{V}(C=0.230)$ differs from zero. With a probability of 0.95 , this supports the existence of a statistically significant relationship between the practice of student employment before studying at university, and while studying at university. To identify the direction of relation, we reduced the respondents answers to two alternatives (Table 1).

Table 1. Distribution of respondents by answers to the hypothesis that pre-university employment affects employment during study.

\begin{tabular}{|c|c|c|c|c|c|c|c|}
\hline $\begin{array}{c}\text { "Did You } \\
\text { Work before } \\
\text { Study?" }\end{array}$ & \multicolumn{2}{|c|}{$\begin{array}{c}\text { "Are You Currently Working in } \\
\text { Addition to Studying?" }\end{array}$} & Total & $\begin{array}{c}O R \\
\left(O R_{L 95 \%}-O R_{U 95 \%}\right)\end{array}$ & $\begin{array}{c}R R \\
\left(R R_{L 95 \%}-R R_{U 95 \%}\right)\end{array}$ & $\begin{array}{c}\chi^{2} \\
\left(\chi^{2} 0.95\right) ; p\end{array}$ & $\begin{array}{l}\mathrm{K} \\
(A)\end{array}$ \\
\hline Yes & 225 & 144 & 369 & \multirow{3}{*}{$\begin{array}{c}2.9 \\
(2.13-3.88)\end{array}$} & \multirow{3}{*}{$\begin{array}{c}1.7 \\
(1.47-2.03)\end{array}$} & 47.6 & \multirow{3}{*}{$\begin{array}{c}0.258 \\
(0.484)\end{array}$} \\
\hline No & 127 & 234 & 361 & & & (3.8) & \\
\hline Total & 352 & 378 & 730 & & & $5 \times 10^{-12}$ & \\
\hline
\end{tabular}

The presence of a direct relationship between the signs is evidenced by the positive values of contingency and association coefficients, and by the relative risk value that is greater than one (Table 1).

The value of the contingency ratio indicates the average strength (density) of the connection. An excess of the calculated $\chi^{2}$ over the theoretical value and the value of the confidence interval for the RR indicator demonstrates the significance (non-randomness) of this relationship at the level of significance of 0.05. Among students who worked before starting their studies, those who worked, while studying at the university were $70 \%$ more common. The odds ratio value demonstrates statistical significance at the level of 0.05 , showing that the chances of working, while studying were almost three times higher for students who worked before studying than for those who did not work before studying. Thus, the hypothetical assumption that pre-university employment affects employment during the study was verified. When the student chose the answer "yes" to at least one of the questions, "Did you work before studying?" and "Are you currently working in addition to studying?", we considered it evidence of the student's practical 
work experience. We considered students as lacking work experience if they answered "no" to the two above-mentioned questions.

The answer to the question, "Do you consider yourself an entrepreneurial person?", was chosen as the second feature. For this question, the questionnaire provided five answer options (Figure 3).

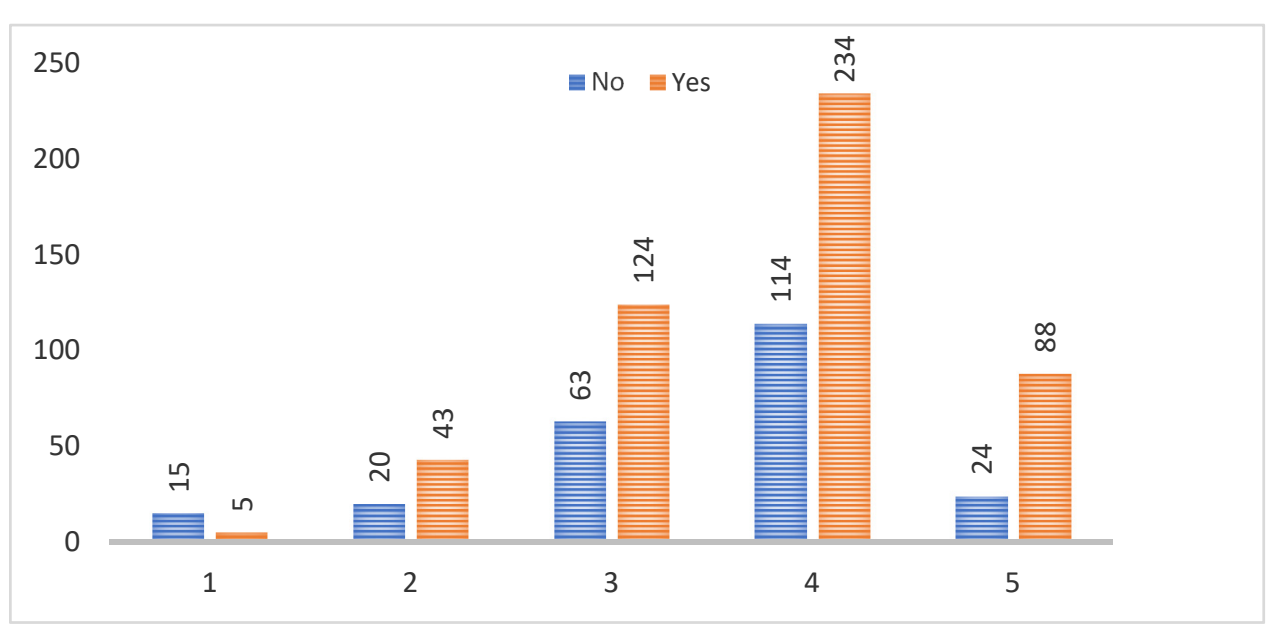

Figure 3. Distribution of respondents' answers to the question regarding the practical work experience of the student (yes, no) and to "Do you consider yourself as an entrepreneurial person?" (1, no; 2, probably no; 3 , neither yes nor no; 4 , rather yes; 5 , yes).

Among these options, the most common answer was "rather yes." The sum of shares for positive answers ("probably yes" $=47.7 \%$ and "yes" $=15.3 \%$ ) is 5.5 times higher than the sum of shares for negative answers ("probably no" $=8.6 \%$ and "no" $=2.7 \%$ ). This indicates that students tended to positively assess their entrepreneurial abilities.

Calculated according to the distribution, which is presented in Figure 3, the value of the Pearson's quadratic conjugation $\left(\chi^{2}=22.9\right)$ is twice higher than the theoretical level $\left(\chi_{0.95}^{2}((2-1) \times(5-1))=9.5\right)$, and the value of Cramér's V $(C=0.177)$ differs from zero, indicating the existence of a relationship between work experience and a sense of confidence in entrepreneurial skills at a level of significance of 0.95 .

The most contradictory were answers to the question, "Do you consider yourself an entrepreneurial person?" (Table 2).

Table 2. Distribution of respondents' answers to address the hypothesis that the presence of practical experience leads to higher confidence in students regarding their entrepreneurial abilities.

\begin{tabular}{|c|c|c|c|c|c|c|c|}
\hline $\begin{array}{c}\text { Work } \\
\text { Experience }\end{array}$ & \multicolumn{2}{|c|}{$\begin{array}{c}\text { “Do You Consider Yourself an } \\
\text { Enterpreneurial Person?" }\end{array}$} & Total & $\begin{array}{c}O R \\
\left(O R_{L 95 \%}-O R_{U 95 \%}\right)\end{array}$ & $\begin{array}{c}R R \\
\left(R R_{L 95 \%}-R R_{U 95 \%}\right)\end{array}$ & $\begin{array}{c}\chi^{2} \\
\left(\chi^{2} 0.95\right) ; p\end{array}$ & $\begin{array}{c}\mathrm{K} \\
(A)\end{array}$ \\
\hline Yes & 88 & 5 & 93 & \multirow{3}{*}{$\begin{array}{c}11.0 \\
(3.63-33.3)\end{array}$} & \multirow{3}{*}{$\begin{array}{c}1.5 \\
(1.19-1.97)\end{array}$} & 20.9 & \multirow{3}{*}{$\begin{array}{c}0.421 \\
(0.833)\end{array}$} \\
\hline No & 24 & 15 & 39 & & & (3.8) & \\
\hline Total & 112 & 20 & 132 & & & $5 \times 10^{-6}$ & \\
\hline
\end{tabular}

We identified the direction of the relationship as straight and the density of the relationship as moderate. According to Table 2, Fisher's exact criterion was additionally calculated (bilateral). Its value (0.00001) indicates the significance (non-randomness) of the discovered connection.

Among respondents with work experience, those who considered themselves entrepreneurial persons were 1.5 times more common. Those who had work experience were significantly more likely to consider themselves entrepreneurial than those who did not. The obtained results are statistically significant, thus supporting the hypothesis that practical experience leads to higher confidence in students regarding their entrepreneurial abilities. 
In the questionnaire, five answer options were provided to the question, "Are you going to start your own business?" (Figure 4).

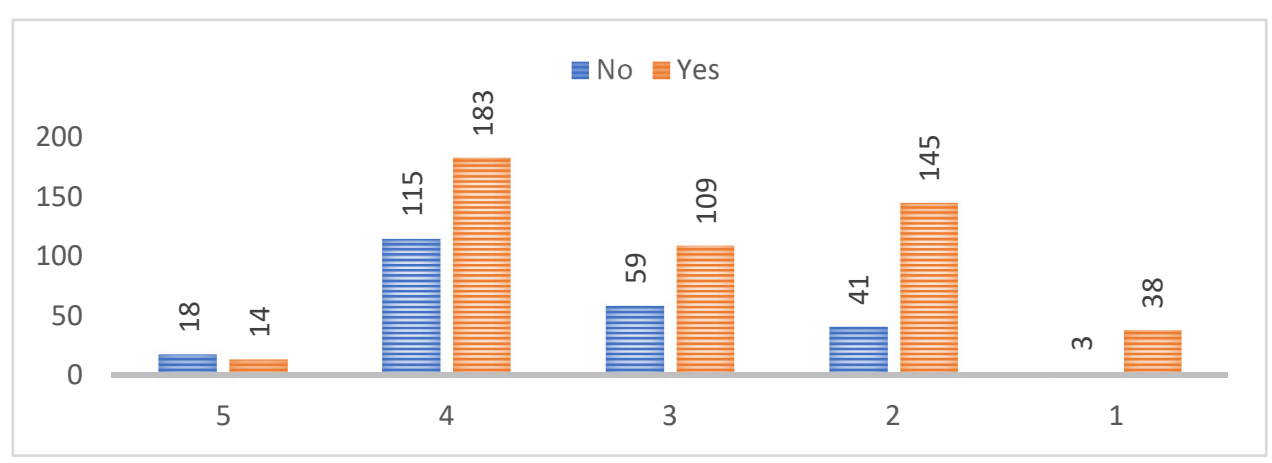

Figure 4. Distribution of respondents' answers to the question about work experience (yes, no) and intention to start their own business (1, I have my own business; 2 , yes, in the next three years; 3, yes, but first I will gain professional experience; 4, I do not reject this option; 5, no).

The answer "I do not reject this option" dominated (41.1\%). The next most frequent answers were "yes, in the next three years" and "yes, but first I will gain professional experience", at $25.7 \%$ and $23.2 \%$, respectively. The $5.7 \%$ of respondents reporting owning their own business indicates their high potential for entrepreneurial competence. Calculated according to the distribution, which is presented in Figure 4, the value of the Pearson's quadratic conjugation $\left(\chi^{2}=34.9\right)$ is three times higher than the theoretical level $\left(\chi^{2} 0.95((2\right.$ $-1) \times(5-1))=9.5)$, and Cramer's V $(C=0.217)$ differs from zero, indicating the existence of a relationship between the traits studied at the level of significance of 0.95 .

The direct connection between work experience and the intention to start one's own business is more clearly demonstrated by the results of grouping by alternative criteria (Table 3): Students who had work experience reported an almost a four-times-higher chance of starting their own business. Among students with work experience, those who focused on entrepreneurship were $10 \%$ more common to do so. Thus, the third hypothesis that the presence of practical experience has a positive effect on students' intentions to start their own business is supported.

Table 3. Distribution of respondents 'answers regarding the hypothesis that practical experience has a positive effect on students' intentions to start their own business.

\begin{tabular}{|c|c|c|c|c|c|c|c|}
\hline \multirow{2}{*}{$\begin{array}{c}\text { Work } \\
\text { Experience }\end{array}$} & \multicolumn{2}{|c|}{$\begin{array}{c}\text { "Are You Going to Start Your } \\
\text { Own Business?" }\end{array}$} & \multirow[t]{2}{*}{ Total } & \multirow{2}{*}{$\begin{array}{c}O R \\
\left(O R_{L 95 \%}-O R_{U 95 \%}\right)\end{array}$} & \multirow{2}{*}{$\begin{array}{c}R R \\
\left(R R_{L 95 \%}-R R_{U 95 \%}\right)\end{array}$} & \multirow{2}{*}{$\begin{array}{c}\chi^{2} \\
\left(\chi^{2} 0.95\right) ; p\end{array}$} & \multirow{2}{*}{$\begin{array}{l}\mathrm{K} \\
(A)\end{array}$} \\
\hline & Yes & No & & & & & \\
\hline Yes & 292 & 14 & 306 & \multirow{3}{*}{$\begin{array}{c}3.6 \\
(1.75-7.59)\end{array}$} & \multirow{3}{*}{$\begin{array}{c}1.1 \\
(1.03-1.21)\end{array}$} & 11.8 & \multirow{3}{*}{$\begin{array}{c}0.176 \\
(0.569)\end{array}$} \\
\hline No & 103 & 18 & 121 & & & (3.8) & \\
\hline Total & 395 & 32 & 427 & & & $6 \times 10^{-4}$ & \\
\hline
\end{tabular}

The questionnaire also asked about experience with assistance in managing a company (Figure 5). Only those students who previously stated that they had acquaintances (relatives) entrepreneurs could answer to the question about their experience in managing a company according to the survey methodology.

Calculated according to the distribution, shown in Figure 5, the Pearson's quadratic conjugation value $\left(\chi^{2}=62.7\right)$ and Cramér's V $(C=0.339)$ exceed similar values calculated according to the distribution, shown in Figure 4, indicating a relationship between experience with managing a company and the intention to start their own business, and a higher moderate consistency of respondents' answers to this question, at a level of significance of 0.95. The results of the analysis in Table 4 indicate the presence of an inverse relationship between the factors. 


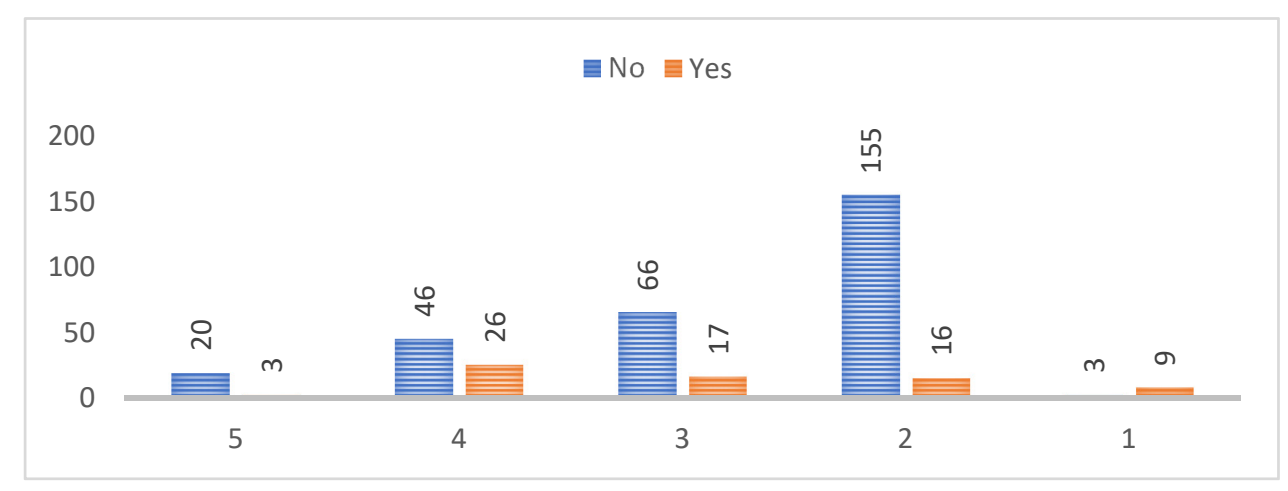

Figure 5. Distribution of respondents' answers to the question about their experience with assistance in managing a company (yes, no) and intention to start their own business (1, I have my own business; 2 , yes, in the next three years; 3 , yes, but first I will gain professional experience; 4 , I do not reject this option; 5 , no).

Table 4. Distribution of respondents' answers within the framework to address the hypothesis that experience with company management has a positive effect on students' intentions to start their own business.

\begin{tabular}{|c|c|c|c|c|c|c|c|}
\hline \multirow{2}{*}{$\begin{array}{c}\text { Experience with } \\
\text { Assistance in } \\
\text { Managing a Company }\end{array}$} & \multicolumn{2}{|c|}{$\begin{array}{l}\text { "Are You Going to Start } \\
\text { Your Own Business?" }\end{array}$} & \multirow[t]{2}{*}{ Total } & \multirow{2}{*}{$\begin{array}{c}O R \\
\left(O R_{L 95 \%}-O R_{U 95 \%}\right)\end{array}$} & \multirow[t]{2}{*}{$\begin{array}{c}R R \\
\left(R R_{L 95 \%}-R R_{U 95 \%}\right)\end{array}$} & \multirow[t]{2}{*}{$\begin{array}{c}\chi^{2} \\
\left(\chi^{2} 0.95\right) ; p\end{array}$} & \multirow[t]{2}{*}{$\begin{array}{c}\mathrm{K} \\
(A)\end{array}$} \\
\hline & & No & & & & & \\
\hline Yes & 63 & 26 & 89 & \multirow{3}{*}{$\begin{array}{c}0.3 \\
(0.12-0.51)\end{array}$} & \multirow{3}{*}{$\begin{array}{c}0.8 \\
(0.67-0.90)\end{array}$} & 14.9 & \multirow{3}{*}{$\begin{array}{l}-0.252 \\
(-0.59)\end{array}$} \\
\hline No & 151 & 16 & 167 & & & (3.8) & \\
\hline Total & 214 & 42 & 256 & & & $1 \times 10^{-4}$ & \\
\hline
\end{tabular}

Lack of experience in managing a company did not create obstacles for young people to plan to start a business. Thus, the hypothesis that students who have experience helping company management are more likely to start their own business is rejected. This finding can be explained by the specifics of modern youth; they are ambitious and confident regarding their entrepreneurial competencies.

\section{Discussion}

Modern science requires the expansion of the range of factors addressed in forming the qualitative parameters of human potential. Here, we focused on one of such factors, student work experience, and proved that such experience contributes to increased students' entrepreneurial intentions.

This conclusion is not in agreement with those of other researchers. Our results differ from the results of many foreign authors, namely, Basu and Virick [23] in the United States; Wah et al. [24] in Malaysia; and Torres et al. [25] in Chile, Colombia, Ecuador, Peru, and Venezuela.

These differences may be due to the differences in the mental characteristics and living conditions of students in different countries. The results of this study provide an example of the situation in Eastern Europe.

In the era of digitalization and distance learning, which has become widespread given the influence of the COVID-19 pandemic, the labor force, including student youth, is reevaluating the feasibility of starting their own business or employment options. The results of our study may provide the basis for comparison with the era just prior to COVID-19.

\section{Conclusions}

International norms of educational activity are aimed at forming entrepreneurial competence in students. Motivational readiness to implement these learned entrepreneurial competencies of student youth in practice reflects the potential for entrepreneurship development.

Despite the student youth social group belonging to the category of economically inactive population, students are traditionally engaged in social production. New changes 
in labor conditions and the use of higher education services contribute to the growing trend of students who combine study and work.

In the framework of this research, we showed that students who were employed before starting their studies at university combined their studies at university with engagement in social production (hypothesis 1 was supported). Having such employment experience increased students' confidence regarding their entrepreneurial abilities (hypothesis 2 was supported) and had a positive effect on students' intentions to start their own business (hypothesis 3 was supported). Hypothesis 4 (having experience helping to manage a company has a positive effect on students' intentions to start their own business) was rejected. Simultaneously, the lack of experience in assistance with management did not constrain students' intentions to start a business.

We see prospects for further research in expanding the analytical space, using student distribution by sex, branch of knowledge, university, and country. Future scientific research may focus on the justification of recommendations concerning the improvement in the effectiveness of students' entrepreneurial intentions formation.

Author Contributions: Conceptualization, N.C. and O.K.; methodology, N.C. and L.H.; software N.C. and M.G.; validation, N.C. and M.G.; formal analysis, O.K. and L.H.; investigation, N.C. and O.K.; resources, N.C. and O.K.; data curation, N.C. and O.K., writing - original draft preparation, N.C. and O.K.; writing-review and editing, O.K. and L.H.; visualization, O.K. and L.H.; supervision, N.C. and M.G.; project administration, N.C. and M.G.; funding acquisition, O.K. All authors have read and agreed to the published version of the manuscript.

Funding: This research received no external funding.

Data Availability Statement: The data presented in this study are available on request from the corresponding author. The data are not publicly available due to agreement with partners in other countries who conducted a simultaneous analogical research in their respective countries.

Conflicts of Interest: The authors declare no conflict of interest.

\section{References}

1. On education: Law of Ukraine. Nr 2145-VIII. 2017. Available online: http://zakon3.rada.gov.ua/laws/show/2145-19 (accessed on 9 October 2020).

2. ANNEX to the Proposal for a Council Recommendation on Key Competences for Lifelong Learning. 2018. Available online: https: / / ec.europa.eu/education/sites/education/files/annex-recommendation-key-competences-lifelong-learning.pdf (accessed on 9 October 2020).

3. Hrynkevych, O.S. Secondary employment of student youth in Ukraine in the context of the analysis of its educational and professional values. Sci. Her. Kherson State Univ. Ser. Econ. Sci. 2016, 19, 127-130.

4. Idarti, N.; Rostiani, R.; Nastiti, T. Underlying factors of entrepreneurial intentions among Asian Students. South East Asian J. Manag. 2010, 4, 143-159.

5. Miranda, F.J; Chamorro-Mera, A.; Rubio, S. Academic entrepreneurship in Spanish universities: An analysis of the determinants of entrepreneurial intention. Eur. Res. Manag. Bus. Econ. 2017, 23, 113-122. [CrossRef]

6. Fatoki, O. The entrepreneurial intention of undergraduate students in South Africa: The influences of entrepreneurship education and previous work experience. Mediterr. J. Soc. Sci. 2014, 5, 294-299. [CrossRef]

7. Bell, R. Predicting entrepreneurial intention across the university. Educ. Train. 2019, 61, 815-831. [CrossRef]

8. Herman, E. Entrepreneurial Intention among Engineering Students and Its Main Determinants. Procedia Manuf. 2019, 32, 318-324. [CrossRef]

9. Asimakopoulos, G.; Hernández, V.; Peña Miguel, J. Entrepreneurial intention of engineering students: The role of social norms and entrepreneurial self-efficacy. Sustainability 2019, 11, 4314. [CrossRef]

10. Saleh, H.; Idris, M. Determinant factors of entrepreneurial intention (case study of management student, Bosowa University). J. Eng. Appl. Sci. 2019, 14, 2163-2170. [CrossRef]

11. Li, L.; Wu, D. Entrepreneurial education and students' entrepreneurial intention: Does team cooperation matter? J. Glob. Entrep. Res. 2019, 9, 35. [CrossRef]

12. Iwu, C.G.; Opute, P.A.; Nchu, R.; Eresia-Eke, C.; Tengeh, R.K.; Jaiyeoba, O.; Aliyu, O.A. Entrepreneurship education, curriculum and lecturer-competency as antecedents of student entrepreneurial intention. Int. J. Manag. Educ. 2019, 19, 100295. [CrossRef]

13. Prokopenko, O.; Osadchenko, I.; Braslavska, O.; Malyshevska, I.; Pichkur, M.; Tyshchenko, V. Competence approach in future specialist skills development. Int. J. Manag. 2020, 11, 645-656. 
14. Şahin, F.; Karadağ, H.; Tuncer, B. Big five personality traits, entrepreneurial self-efficacy and entrepreneurial intention: A configurational approach. Int. J. Entrep. Behav. Res. 2019, 25, 1188-1211. [CrossRef]

15. Arranz, N.; Arroyabe, M.F.; Fdez de Arroyabe, J.C. Entrepreneurial intention and obstacles of undergraduate students: The case of the universities of Andalusia. Stud. High. Educ. 2019, 44, 2011-2024. [CrossRef]

16. Usman, B. Understanding the entrepreneurial intention among international students in Turkey. J. Glob. Entrep. Res. 2019, 9, 10. [CrossRef]

17. Pryschepa, S.M. The essence and content of the concept of "entrepreneurial competence". Young Sci. 2016, 5, 367-370.

18. Moldavan, A.D. Entrepreneurial competence in the field of physical culture and sports: Content and essential characteristics. ScienceRise Pedagog. Educ. 2020, 1, 36-40. [CrossRef]

19. Sheligan, O.N. Entrepreneurial competence in scientific receptions of scientists. Pedagogical education: Theory and practice. Psychol. Pedagog. 2019, 31, 86-90.

20. Myhovych, I. Entrepreneurial competence in the context of internationalization of national higher education systems: Institutional level. Collect. Sci. Work. Um. State Pedagog. Univ. 2019, 3, 137-149.

21. Seredina, I. Entrepreneurial competence of future bachelors in business economics as a scientific and pedagogical problem. Sci. Bull. Inst. Vocat. Education. Ser. Prof. Pedagog. 2018, 16, 94-100.

22. Havran, V.; Havran, M. The process of research products commercialization at higher education institutions: Foreign experience and Ukrainian reality. J. Lviv. Polytech. Natl. Univ. Ser. Econ. Manag. Issues 2019, 897, 92-97. (In Ukrainian) [CrossRef]

23. Basu, A.; Virick, M. Assessing Entrepreneurial Intentions Amongst Students: A Comparative Study. Natl. Coll. Invent. Innov. Alliance 2008, 5, 79-86.

24. Wah, L.F.; Yusuf, B.N.M.; Suanda, J. A study on factors affecting entrepreneurial intentions among students in higher education institutions in northern regions of Malaysia. Int. J. Inf. Technol. Bus. Manag. 2017, 58, 80-99.

25. Torres, F.C.; Méndez, J.C.E.; Barreto, K.S.; Chavarría, A.P.; Machuca, K.J.; Guerrero, J.A.O. Exploring entrepreneurial intentions in Latin American university students. Int. J. Psychol. Res. 2019, 10, 46-59. 